\title{
Effects of Differential Presentation of Noun Types on Sentence Processing in Elderly Adults: An Eye- tracking Study
}

\author{
Suji Kim, Jee Eun Sung \\ Department of Communication Disorders, Ewha Womans University, Seoul, Korea
}

Correspondence: Jee Eun Sung, PhD Department of Communication Disorders, Ewha Womans University, 52 Ewhayeodae-gil, Seodaemun-gu, Seoul 03760, Korea

Tel: $+82-2-3277-2208$

Fax: +82-2-3277-2122

E-mail: jeesung@ewha.ac.kr

Received: July 5, 2021

Revised: July 29, 2021

Accepted: August 5, 2021

This research was supported by the National Research Council of Science \& Technology(NST) grant by the Korea government (MSIT) (No. CAP21051-000).

This article is a revision of the first author's master's thesis.
Objectives: The purpose of this study is to investigate how aging influences sentence processing when noun-phrases are presented differently. Methods: A total of 40 participants participated in the study ranging in age from 19 to 71 . All were presented with sentences and pictures under either dative or accusative conditions. After that, they were asked to judge if the sentences were correct or incorrect. Results: First, there were significant differences between the older adults and younger adults in accuracy. The older group showed lower accuracy in the sentence judgment task. Second, there were significant differences between the older adults and younger adults in response time. The older group needed more time due to their lower cognitive resources. They made more errors when accusative noun phrases were provided. Third, the fixation proportion of the target stimulus between regions were significant in both types of dative and accusative noun phrase presentation. The older group showed lower proportions in the last region of the sentence. Conclusion: These results shows that both the elderly and the young gradually deal with the meaning of words through the noun phrase information. However, the elderly showed difficulty in assigning the correct thematic roles by using case-markers, given the lower proportion of fixation in the region where the target stimuli are presented. It is expected that difficulties in the communication process of the elderly will be better understood through this study.

Keywords: Sentence processing, Eye-tracking, Noun-phrase, Aging 문장처리(sentence processing)는 실시간으로 빠르게 일어나며, 여러 단계의 인지 과정을 거친다. 이 과정에서 운율이나 소리와 같 은 초분절적(suprasegmental) 정보를 포함한 통사 및 의미 정보를 신속하게 지각하고 조합하며(Park, Cho, \& Chung, 2016), 상황과 배경 지식을 이용해 발화자의 의도를 파악하게 된다. 따라서 문장 처리 과정은 다양한 기제가 동원될 뿐 아니라 문맥과 환경의 영향 을 받는 복잡한 과정이라고 할 수 있다(Brown-Schmidt \& Tanenhaus, 2008; Hagoort \& Van Berkum, 2007; Kamide, Altmann, \& Haywood, 2003; Schwanenflugel \& LaCount, 1998; Wlotko \& Federmeier, 2012).

이러한 문장처리 과정에서 문장 성분들 간에 동사를 중심으로 의미적 관계를 가지게 되며, 이를 의미역(thematic role)이라고 한다. 의미역에 관한 분석은 문장 성분 간의 관계를 파악하여 문장의 전
체 의미를 파악하는데 매우 중요한 역할을 한다(Park et al., 2016). 영어와 같이 주어-동사-목적어(Subject-Verb-Object, SVO) 어순을 가지는 언어에서는 동사가 가지고 있는 구조적, 의미적 특징에 따 라 뒤에 제시되는 명사구의 의미역을 예측하며 문장을 처리하게 된 다(Altmann \& Kamide, 1999). 시선추적기법(eye-tracking)과 같은 실시간 문장처리(real-time sentence processing) 방법론을 적용하 여 살펴본 연구에 따르면, 동사가 제시될 때 대상자의 시선이 문장 내 후속 성분에 해당하는 목표 자극으로 이동하여 시선이 고정되 는 비율을 분석하여, 동사가 제시될 때, 이미 후속 정보에 대한 명 사구 의미역을 예측하여 시선이 이동함을 확인하였다. 이와 같이 $\mathrm{SVO}$ 어순 구조를 가진 언어에서는 동사가 다음 명사구에 예측 변 인을 내재하고 있어 실시간으로 처리되는 문장 이해 과정에서의 점 진적 처리(incremental processing) 기제에 의존한다는 가설을 증 
명하였다(Tanenhauss, Carlson, \& Trusewell, 1989).

하지만, 한국어와 같이 주어-목적어-동사(Subject-object-verb, $\mathrm{SOV}$ ) 어순을 사용하는 동사후치어(verb-final language)의 경우, 같은 가설을 적용하기에 한계가 있다. 조사체계(case marking system)가 발달하여 비교적 자유어순이 가능한 한국어와 같은 언어 권에서는 동사를 통해 의미역을 예측하기보다는 명사구에 결합하 는 조사와 같은 형태론적 정보가 의미역 처리에 주요 단서가 되기 때문이다(Kim \& Woo, 2007). Kamide 등(2003)은 동사가 문장의 말미에 등장하는 언어권에서 명사구의 격조사 정보를 통해 의미역 을 예측할 수 있는지 알아보고자 일본어를 대상으로 연구를 실시 하였다. 통사적 구조의 전형성을 근거로 여격(dative) 문장 ‘종업원 이 손님에게 즐겁게 햄버거를 줄 것이다'(The waitress will merrily bring the hamburger to the customer)와 대격(accusative) 문장 '종 업원이 손님을 즐겁게 놀릴 것이다'(The waitress will merrily tease the customer)를 사용하였다. 여격 문장의 경우 여격 명사구 '-에 게’ 이후 대격 명사구 ‘-을'이 등장하는 것이 전형적이기 때문에 일 본어 사용자가 여격 명사구 ‘손님에게’를 듣고 이후의 의미역에 해 당하는 '햄버거를'을 쉽게 예측할 것이라고 가정하였다. 반면 대격 문장의 경우 대격 명사구 '-을' 이후에 동사가 나오는 구조가 전형 적이어서 '햄버거를'에 해당하는 그림을 보지 않을 것으로 예상했 다. 이러한 패러다임으로 실험한 결과, 여격 문장의 ‘손님에게’를 들 었을 때 '햄버거를'을 예측하는 비율이 대격 문장의 '손님을'을 들었 을 때 '햄버거를'을 예측하는 비율보다 유의하게 높았다. 또한, SOV 언어인 한국어를 대상으로 연구한 Lee (2019)의 보고에 따르면, 한 국어 문장처리 과정에서도 격조사가 후행하는 의미역 예측에 주요 한 단서가 된다는 것으로 다시 한번 확인하였다. 즉, 여격 명사구 '에게'가 먼저 제시될 때, 후행하는 대격 명사구 및 타동사가 제시될 것임을 예측 가능하였으나, 대격 명사구가 제시될 때는 다른 명사 구가 추가적으로 후행할 것이라는 예측률이 현저하게 낮아졌다. 즉, 한국어 연구에서 또한, 여격 명사구가 제시되었을 때, 후행하는 명사구 의미역 예측에 근거하여 목표 자극으로의 시선고정비율이 증가하는 것을 확인하였다. 이러한 연구결과를 종합하면, SOV 어 순을 가진 언어권에서 SVO 언어권 결과와는 달리, 동사보다는 명 사구의 격조사 정보가 후행하는 문장 성분의 정보를 예측하는데 주요한 단서가 될 수 있음을 확인할 수 있다.

노화가 진행됨에 따라 문장처리 능력이 감소한다는 연구가 다양 하게 보고되고 있다(Gordon-Salant \& Fitzgibbons, 2004; Kim \& Kim, 2009; Wingfield \& Grossman, 2006). 문장처리 능력은 인지 기제(cognitive construct)의 영향으로부터 자유로울 수 없으며, 노 년층의 경우 문장처리와 밀접하게 관련된 작업기억(working memory)과 같은 인지능력이 감퇴하고(Schneider, Danman, \& Pichora-Fuller, 2002), 정보처리속도(information processing speed) 또한 저하된다는 연구가 이러한 가설을 뒷받침한다. 실시간 정보처 리가 요구되는 문장처리 과정에서 앞에서 설명한 의미역 예측 과정 은 실시간으로 입력되는 단어들이 제공하는 정보와 문맥적 정보를 이용해야 하는 복잡한 처리 과정이다(Kamide et al., 2003). 노년층 은 기존의 정보를 통해 새로 나올 정보를 예측하는 능력이 저하되 기 때문에, 의미역 예측 과정에서도 어려움을 보인다(Federmeier, McLennan, De Ochoa, \& Kutas, 2002). Hwang과 Sung (2019)은 한국어 동사의 의미를 통한 의미역 예측 실험을 통해 노년층이 청 년층에 비해 예측력이 저하되어 정확도와 반응시간에서 수행력이 낮음을 보고하였다. 따라서 격조사가 포함된 명사구를 통해 의미 역을 예측하는 것은 노화에 따라 영향을 받을 수 있으며, 이러한 연 구를 통해 실시간 문장처리에서 노화가 나타나는 지점을 보다 명 확하게 살펴볼 수 있을 것이다.

실시간 문장처리 연구는 사건관련전위(event-related brain potentials, ERP), 기능적 자기공명영상법(functional magnetic resonance imaging, fMRI), 시선추적(eye-tracking) 등의 다양한 기술 을 활용하여 진행되어 왔다(Kemmer, Coulson, De Ochoa, \& Kutas, 2004; Kim, Sung, Lee, \& Sim, 2018; Stine-Morrow, Noh, \& Shake, 2010). 이 가운데 시선추적기법은 대상자가 문장을 처리하 는 과정 동안의 시선의 움직임을 추적하여, 대상자가 인지적 처리 를 위해 정보를 획득하고 처리하는 과정을 확인할 수 있다(Kim, 2020). 이러한 시선추적기법을 활용하여 문장처리 과정을 알아보 는 연구에서는 보통 시각적 자극을 제시하여 문장처리를 위한 맥 락을 제공한다. 일반적으로 두 가지 이상의 시각적 자극을 제시하 여 청각적 문장에 대한 둘 이상의 충돌하는 해석들 중 하나를 선택 하도록 한다. 정보가 상충되거나 모호할 때 방해 자극으로의 시선 고정이 일어날 수 있으며 이를 통해 대상자의 비효율적이고 혼란스 러운 처리 과정에 대해 이해를 높일 수 있다(Hall, Horne, McGregor, \& Farmer, 2018).

Cooper (1974)는 대상자들이 문장을 들을 때 현재 언급되는 단 어의 참조물을 쳐다보거나 문맥과 관련된 사물로 시선을 움직인다 는 것을 발견했다. 이러한 시선의 움직임은 시간 제한적(time locked) 으로, 단어가 언급되는 중이거나 단어가 언급된 후 $200 \mathrm{~ms}$ 이내에 관련 사물로 시선이 이동된다고 하였다. 따라서 시각적 패러다임 (visual-world paradigm)을 사용하여 특정 대상을 향한 시선의 움 직임을 추적한다면 실시간 문장처리 양상에 대한 이해를 높일 수 있다. 노년층을 대상으로 한 연구를 보면, Rayner, Reichle, Stroud, Williams와 Pollatsek (2006)은 텍스트를 읽을 때 노년층이 청년층 
에 비해 훓어 읽는 경향이 있다고 보고하였으며, 시선추적기법을 통해 텍스트로 향하는 시선의 도약 거리가 노년층에서 더 길다는 것을 근거로 제시했다. 국내에서는 Jang과 Sung (2020)이 '누구'의 문사처리 과정을 통해 노년층이 '누구가' 유형의 질문보다 '누구를' 유형의 질문에서 더 어려움을 보인다고 하였으며, 시선추적기법을 통해 더 어려운 ‘누구를' 유형의 문제에서 목표 자극을 보는 시선고 정시간이 짧았다고 보고했다. 이처럼 시선추적 연구를 통해서 정반 응률이나 반응시간 같은 오프라인(off-line)측정치 외에 시선고정 시간(duration of fixation)이나 시선고정비율(fixation of proportion) 과 같은 온라인(on-line) 측정치를 확인할 수 있다는 장점이 있다.

노년층은 다양한 신체, 인지, 사회적 변화를 경험할 수 있으며 의 사소통의 변화나감퇴도 일상생활의 어려움을 유발하는 중요한 요 인 중 하나이다(Kang, Kim, Seok, Cho, \& Choi, 2001). 노년층의 인 구가 차지하는 비중이 늘어남에 따라 노년층의 삶의 질에 영향을 미칠 수 있는 언어 처리 과정에 대한 연구는 필수적이다. 그 중에서 도 문장처리는 단어 수준보다 문법적으로 복잡한 처리 능력을 요 구하기 때문에 노화에 대한 민감한 지표로 삼을 수 있다(Ferreira \& Cokal, 2015). 그러나 현재 의사소통장애 연구에 있어서 노년층 의 의사소통장애는 주로 뇌졸중이나 퇴행성 신경언어장애 등과 같이 신경장애환자를 중심으로 다루어지고 있으며 정상 노년층의 의사소통 능력에 대한 연구는 드문 실정이다(Kim \& Kim, 2009). 이에 본 연구는 Kamide 등(2003)의 시선추적 실험을 바탕으로 노 년층의 실시간 문장처리 과정에 대해 살펴보고자 한다. 글 읽기에 서 나타나는 시선의 움직임을 추적하는 것이 아닌 그림을 보는 시 선의 움직임을 추적하는 시각적 패러다임을 통해 청각적 문장처리 과정에 대해 살펴볼 수 있어 의미 있을 것으로 생각된다.

요약하면, 본 연구에서는 노년층이 서로 다른 의미를 가지는 시 각적 자극이 제시될 때 격조사가 포함된 명사구의 정보를 통해 의 미역을 예측하고 문장을 처리할 수 있는지 알아보고자 하였다. 구 체적으로, 전형적 서술 구조에 따라 통사적 제약이 높은 여격 명사 구 제시 유형과 제약이 낮은 대격 명사구를 제시하여 명사구 제시 유형이 의미역 예측 및 문장처리에 영향을 미칠 수 있는지 확인해 보고자 하였다 이때 목표 자극으로 향하는 시선의 움직임을 추적 하여 정확도와 반응시간과 같은 양적 수치뿐 아니라 노년층이 어떤 지점에서 어려움을 느끼는지에 대한 질적인 이해 또한 얻을 수 있 을 것으로 기대한다. 본 연구의 연구 질문은 다음과 같다.

1) 명사구 제시 유형(여격 vs. 대격)에 따라 문장이해과제 정반응 률에서 집단(청년층 vs. 노년층) 간 차이가 유의한가?

2) 명사구 제시 유형(여격 vs. 대격)에 따라 문장이해과제 반응시 간에서 집단 (청년층 vs. 노년층) 간 차이가 유의한가?
3) 명사구 제시 유형(여격 vs. 대격)에 따라 구간별 목표 자극 시 선고정비율에서 집단(청년층 vs. 노년층) 간 차이가 유의한가?

\section{연구방법}

\section{연구대상}

본 연구는 수도권에 거주하는 청년층 20 명(남 4 명, 여 16 명), 노년 층 20 명(남 3 명, 여 17 명) 총 40 명을 대상으로 실시하였다. 실험 이 후 보정(calibration) 및 검증(validation) 과정에서 동공의 $\mathrm{X}$ 축과 $\mathrm{Y}$ 축의 편차(Eye Deviation)가 불안정하거나, 시선고정비율이 $30 \%$ 이하인 대상자는 데이터 분석에서 제외하여 청년층 17 명, 노년층 18 명 총 35 명의 데이터가 분석에 사용되었다.

정상 노년층의 연령기준은 고령자고용촉진법에서 정한 55세 이 상과, 노인복지법에서 규정하고 있는 65세 이상의 평균을 구하여 만 60세 이상을 기준으로 선정하였다. 두 집단의 교육년수는 통계 적으로 유의한 차이가 나타나지 않도록 통제하였다 $\left(F_{(1,33)}=.817\right.$, $p>.05)$. 본 연구는 이화여자대학교 연구윤리위원회(IRB)의 심의 를 거쳐 위원회 승인하에 진행되었다(과제 승인번호 ewha-2020080007-01). 모든 대상자는 실험 참가 전에 연구의 목적 및 방법, 연구 참여 동의 및 거부에 대한 권리, 중도 포기 가능, 개인정보 보호 등 에 관한 설명을 듣고 서면으로 동의서에 서명한 뒤 실험에 자발적 으로 참여하였다. 두 집단의 대상자 선정 기준은 다음과 같다. 두 집단 모두 (1) 한국어를 모국어로 사용하고, (2) 건강선별기준(Christensen, Multhaup, Nordstrom, \& Voss, 1991)에 근거한 기준에 따 른 신경학적 및 정신적 병력이 보고되지 않으며, (3) 교육년수가 12 년 이상이고, (4) 자가보고에 의해 시력에 문제가 없으며, (5) 순음 청력검사에 따른 역치가 $500 \mathrm{~Hz}, 1,000 \mathrm{~Hz}, 2,000 \mathrm{~Hz}, 4,000 \mathrm{~Hz}$ 에 서 $25 \mathrm{~dB}$ HL에 속하며(Kang, Lee, Yoon, Shim, \& An, 2015), (6) 서 울신경심리검사 2판(Seoul Neuropsychologic Screening BatteryII, SNSB-II; Kang, Jang, \& Na, 2012)의 하위검사인 K-MMSE 과제 를 통해 연령 및 교육수준에 따라 정상 범위( $16 \%$ ile) 내에 속한다. 정상 노년층 집단은 추가적으로 (1) SVLT (Seoul Verbal Learning Test; Kang \& Na, 2003) (>16\%ile)를 실시하여 규준에 따라 정상 범주(16\%ile)에 속하는 자로 선정하였다.

연구에 참여한 대상자의 정보는 다음 Table 1 에 제시하였다.

\section{연구과제}

실험자극

연구과제는 명사구 제시 유형(여격 vs. 대격)이 문장처리에 미치 는 영향을 살펴보기 위해 선행연구인 Kamide 등(2003)에서 사용 
한 패러다임을 참고하여 자체적으로 제작하였다. 여격 명사구 제시 유형의 경우 전형적 여격 문장의 서술 구조인 '가 -에게 -를'에 따라 여격 명사구 '-에게'를 듣고 '-를'에 해당하는 의미역을 예측할 수 있 는지를 보는 것이다. 대격 명사구 유형의 경우 대격 문장의 전형적 서술 구조인 '가 -를'에 따라 대격 명사구 '-를'을 듣고 의미역을 예 측하지 않거나 부가어인 '-에서'를 예측할 수 있는지 보고자 하는 것이다. 여격 명사구 제시 유형은 통사적 제약이 강해 의미역을 예 측하기 쉬운 조건이고 대격 명사구 제시 유형은 통사적 제약이 약 해 의미역 예측이 비교적 어려운 조건이다.

연구를 위해 사용된 문장은 모두 5 개의 어절로 이루어지며 여격 문장 24 개, 대격 문장 24 개, 메꿈 문장 24 개로 총 72 개이다. 선행연 구에서 대격 문장을 4 개의 어절로 구성한 것과 달리 본 연구에서는 장소 부사구를 추가해 여격 문장과 같은 5 개 어절 문장으로 통제하 였다. 모든 문장은 국립국어원의 현대국어 빈도조사의 빈도수 100 이상인 어휘들로 구성하였다(National Institute of Korean Language, 2005). 여격 문장은 행위자(agent), 도달점(goal)/수혜자(recipient), 대상(theme), 타동사로 구성되며, 대격 문장은 행위자, 대 상, 장소(location), 타동사로 구성되었다. 대상자가 실험의 의도를

Table 1. Demographic information on participants

\begin{tabular}{lcc}
\hline & Young group (N=20) & Elderly group (N=20) \\
\hline Gender & & \\
Male & 4 & 3 \\
Female & 16 & 17 \\
Age (yr) & $24.2(4.5)$ & $66.5(3.9)$ \\
Education (yr) & $13.6(2.24)$ & $14.3(2.6)$ \\
K-MMSE & $30(0)$ & $29.1(1.8)$ \\
SLVT & & \\
IM & N/A & $25.3(3.2)$ \\
$D$ & N/A & $8.55(1.9)$ \\
R & N/A & $11.75(3)$ \\
\hline
\end{tabular}

Values are presented as mean (SD).

K-MMSE = Korean version of Mini-Mental State Examination (Kang, 2006); SVLTIM= Seoul Verbal Learning Test-Immediate recall (Kang et al., 2012); SVLT-D= Seoul Verbal Learning Test-Delayed recall (Kang et al., 2012); SVLT-R=Seoul Verbal Learning Test-Recognition (Kang et al., 2012); N/A= Not Applicable.
파악하여 실험이 왜곡되는 결과를 막기 위해 메꿈(filler) 문장을 만들었으며 실험 문장과 다른 형태의 5 어절 문장으로 구성하였다. 메꿈 문장을 포함한 모든 문장의 첫 번째 명사구와 두 번째 명사구 의 어휘는 가족 지칭어와 중립적인 지칭어를 사용하였으며 2-3음 절로 통일하였다. 문장의 두 번째 명사구 이후에는 패딩(padding) 으로 부사를 추가하여 대상자들이 의미역을 예측할 수 있는 시간 을 제공할 수 있도록 했다.

문장이해과제 단계에서 제시되는 질문은 앞서 제시한 문장의 조 사의 위치를 바꾸거나 명사구의 순서를 바꾸어 의미역 간 관계를 묻는 내용으로 제시되었다. 구체적인 실험 문장과 질문의 예시는 Tables 2, 3에 제시하였고, 전체 실험 문장과 질문 유형 예시는 Appendix 1에 제시하였다.

\section{실험자극 배열}

시각적 자극은 청각적으로 제시되는 문장의 명사구에 해당하는 그림으로 제시하였다. '여격 문장과 대격 문장은 동일한 주어, 즉 행 위자를 공유하며 여격 문장의 여격 명사구인 도달점/수혜자가 대 격 문장에서는 대격 명사구인 대상이 된다. 따라서 두 문장의 명사 구에 해당하는 행위자, 도달점/수혜자, 대상과 장소를 나타내는 4 개의 그림을 한 화면에 배치하였다. 한 화면에 나타나는 두 인물은 세상사 지식을 통해 구별할 수 있도록 연령이나 성별을 다르게 설 정하였다. 문장의 조건 별로 자극의 위치는 다르게 배치하여 제시 하였다. 그림의 색이 시선 움직임에 영향을 미치는 배색 효과(color effect)를 차단하기 위해 모든 그림 자극은 흑백 선화로 선정하였다. 먼저 Google.com과 Storyset.com에서 그림을 수집한 후 Power-

Table 3. Example of questions

\begin{tabular}{c}
\hline Question \\
\hline $\begin{array}{l}\text { Dative } \\
\text { Old man-ekye (Dat.) uncle-ie (Nom.) bicycle-ul (Acc.) pass (past. Int.) }\end{array}$ \\
$\begin{aligned} \text { Accusative Neighbor-ul (Acc.) dad-ka (Nom.) hallway-esey (Loc.) see (past. Int.) } \\
\text { Uncle-ul (Acc) old man-ie (Nom.) hometown -esey (Loc.) greet (past. Int.) }\end{aligned}$
\end{tabular}

Dat. $=$ Dative; Nom. = Nominative; Acc. $=$ Accusative; Int. = Interrogative; Loc. $=$ Locative.

Table 2. Example of sentence stimuli

\begin{tabular}{llllll}
\hline & \multicolumn{1}{c}{ NP1 } & NP2 & ADV & NP3 & VP \\
\hline Dative & Dad-ka (Nom.) & Neighbor-ekye (Dat.) & Yesterday & Fruit-ul (Acc.) & Sell (past. Dec.) \\
& Uncle-ie (Nom.) & Old man-ekye (Dat.) & By himself & Bicycle-ul (Acc.) & Pass (past. Dec.) \\
Accusative & Dad-ka (Nom.) & Neighbor-ul (Acc.) & Yesterday & Hallway-esey (Loc.) & See (past. Dec.) \\
& Uncle-ie (Nom.) & Old man-ul (Acc.) & By himself & Hometown-esey (Loc.) & Greet (past. Dec.) \\
\hline
\end{tabular}

Nom. = Nominative; Dat. = Dative; Acc. =Accusative; Dec. = Declarative; Loc. $=$ Locative; NP1 = Noun phrase 1; NP2 = Noun phrase 2; ADV=Adverb; NP3=Noun phrase 3; $\mathrm{VP}=$ Verb phrase. 


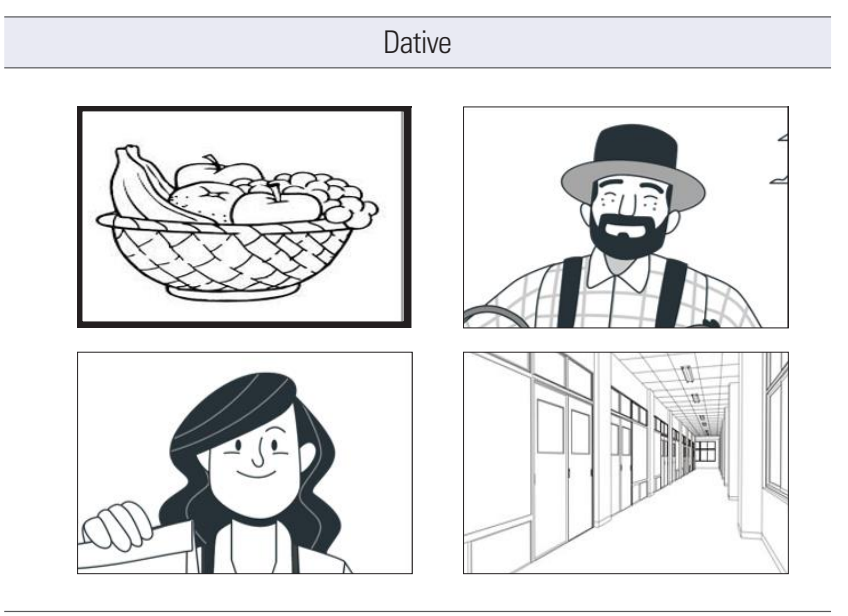

Dad-Nom. neighbor-Dat. yesterday fruit-Acc. sell-past.Dec.

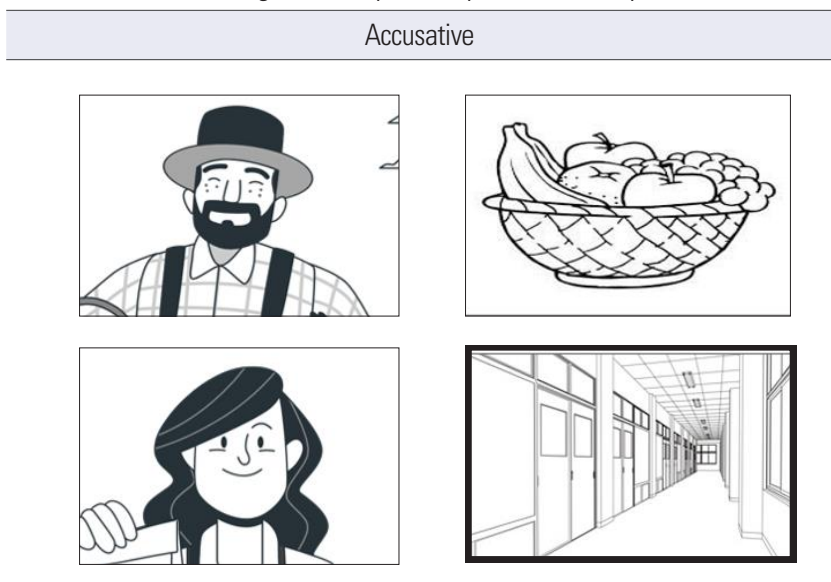

Dad-Nom. neighbor-Acc. yesterday hallway-Loc. see-past.Dec.

Figure 1. Experimental stimuli for each condition.

Nom.$=$ Nominative; Dat. $=$ Dative; Acc. $=$ Accusative; Dec. $=$ Declarative; Loc. $=$ Locative.

point 2016을 이용하여 색깔 보정과 크기 작업을 거쳐 완성하였다. 구체적인 실험자극 배열 예시는 Figure 1에 제시하였으며 명사구 제시 유형 간 목표 그림은 진한 박스로 표시하였다.

타당도

실험 자극의 타당도를 알아보기 위해 정상 성인 18 명을 대상으 로 실험 문장과 시각 자극 간 5점 척도 평정을 실시하였다. 구글 (Google) 설문지를 이용하여 참여자들이 자발적으로 평가할 수 있 게 하였다. 문장 내 명사구와 명사구에 해당하는 그림 자극을 제시 하고 그림 자극이 명사구의 의미를 전달할 수 있는지 매우 부적절 함(1점)부터 매우 적절함(5점)까지 평가하도록 하였다. 3점 미만을 받은 그림들을 새 그림으로 교체하여 다시 평가하고 평균 3점 이상 의 그림들을 최종자극으로 사용하였다.

\section{연구도구}

본 연구는 화면을 보는 대상자의 안구 움직임을 추적하기 위해 시선추적기(Eye-tracker)를 활용하였다. 장비에 설치한 카메라로 대상자의 눈에 적외선을 투사하면 대상자의 각막에서 빛이 반사되 며 이 각막광(corneal glint)을 통해 안구의 움직임을 추적하고 측정 하는 방식이다. SMI (Senso Motoric Instruments)사의 'Expriment 3.7'프로그램을 이용하여 실험을 설계하였고, ivew XTM RED 장 비를 사용하여 시선의 움직임을 기록하였다. 실험이 끝난 후 시선 움직임에 대한 분석은 ‘BeGaze 3.7’프로그램을 이용하였다.

그림 자극은 $1,920 \times 1,080$ 해상도의 19 인치 모니터 각 코너에 가 로 $30 \%$, 세로 $20 \%$ 의 비율로 한 화면 당 4 개씩 동일하게 제시되었다.

음성 자극은 소음이 차단된 조용한 방에서 성인 여성의 목소리 로 녹음하였다. 컴퓨터에 마이크를 연결한 후 마이크와 입의 거리 를 $10 \mathrm{~cm}$ 두고 억양과 속도를 동일하게 유지하여 녹음하였다. 문장 의 모든 어절은 $2,000 \mathrm{~ms}$ 마다 제시되었다. 녹음된 음원은 Audacity (R) ver 2.4.2 (Team, 2020)을 이용하여 소음을 제거하고 각 어절 사 이의 쉼을 조절하여 문장제시단계에서 제시되는 문장 자극은 총 $10,000 \mathrm{~ms}$ 동안, 질문제시단계에서 질문은 총 $8,000 \mathrm{~ms}$ 동안 제시 될 수 있도록 통제하였다.

\section{연구절차}

본 실험은 방음 시설이 갖추어진 조용한 장소에서 개별적으로 실 시하였다. 연구자는 대상자에게 실험의 목적 및 순서에 대해 설명 하고 시선추적기가 설치된 컴퓨터 화면 앞에 앉을 수 있도록 하였 다. 시선추적기와 대상자 간의 거리는 60-70 $\mathrm{cm}$ 로 조정하였다. 시 각 자극은 컴퓨터 화면의 각 코너 부분에 제시되었으며 청각 자극 은 스피커를 통해 제시되었다. 대상자가 답을 예측하는 것을 방지 하기 위해 모든 문항은 여격 문장, 대격 문장, 메꿈 문장을 한 세트 로 하여 같은 형식의 문장이 연속으로 제시되지 않도록 하였다. 목 표 시각 자극 역시 연달아서 같은 위치에 나오지 않도록 조정하여 제시하였다,

실험의 순서는 (1) 보정단계, (2) 연습 문항, (3) 문장 제시, (4) 문장 이해과제 순으로 진행되었다. 먼저 보정단계에서 대상자는 고정대 에 턱을 고정하고 시선이 시선추적기가 허용하는 각도 및 범위 내 에 있는지 확인하는 보정(calibration)단계를 거쳤다. 화면에 빨간 점이 나오면 고개는 움직이지 않고 시선만 움직여 빨간 점을 따라 가야 한다고 안내했다. 보정단계를 거친 후 본 문항을 실시하기 전 에 연습 문항을 실시하여 과제 진행 방법에 대해 숙지할 수 있도록 했다. 대상자에게 '그림과 함께 문장이 제시됩니다. 그 후 문장의 내 용에 대한 질문이 제시됩니다. 잘 들으시고 질문에 맞는 대답을 '예' 
또는 '아니오'로 눌러주시기 바랍니다'라는 지시사항을 들려주었 다. 조건별로 2 문항씩 총 4 문항을 실시하여 대상자가 과제에 대해 충분히 이해할 수 있는 시간을 제공했다. 총 문항은 72 문항으로 2 개의 리스트를 만들어 대상자마다 다른 리스트를 교대로 제공해 실험을 진행하였다. 72 문항 중 24 문항을 진행하고 나면 앞서 진행 했던 보정단계를 위해 빨간 점이 화면에 다시 제시되는데 이때 휴 식을 원할 시 휴식 시간을 제공한 후 다음 문항을 진행하도록 했다.

연습 문항을 실시한 후 본 과제가 시작되기 전 빈 화면이 $1,000 \mathrm{~ms}$ 동안 제시된 후 응시점 '+'이 화면 중앙에 $150 \mathrm{~ms}$ 동안 제시되었다. 이 단계는 대상자의 시선을 화면 중앙으로 유도하기 위해 실시되었 다. 본 과제인 (3) 문장 제시 단계에서는 청각적 자극이 시각적 자극 과 함께 제시되었다. 이 단계에서 대상자는 키보드를 조작하거나 문장에 대해 판단을 하지 않고 시각적 맥락이 제시되었을 때 청각 적으로 제시되는 문장을 이해하여야 한다. 청각적 자극은 10,000 $\mathrm{ms}$ 동안 제시되었으며, 여격 문장의 경우 '아빠가 이웃에게 어제 과 일을 팔았다', '삼촌이 노인에게 직접 자전거를 건넸다'의 형식이며 대격 문장의 경우 '아빠가 이웃을 어제 복도에서 보았다', '삼촌이 노인을 직접 고향에서 맞았다'의 형식으로 제시하였다. (4) 문장이 해과제 단계에서는 빈 화면이 $1,000 \mathrm{~ms}$ 동안 나타나고 질문이 8,000 $\mathrm{ms}$ 동안 청각적으로 제시되었다. 질문 형식은 앞서 제시된 실험 문 장의 조사의 위치를 바꾸거나 명사구의 순서를 바꾸어 '아빠에게 이웃이 과일을 팔았습니까?'와 ‘노인에게 삼촌이 자전거를 건넸습 니까?' 또는 ‘이웃을 아빠가 복도에서 보았습니까?'와 '삼촌을 노인 이 고향에서 맞았습니까?'처럼 의미역 관계를 묻는 방식으로 제시
되었다. 여격 문장과 대격 문장 모두 어순만 바꾸어 제시한 질문, 의 미역 관계를 바꾸어 제시한 문항 수를 동일하게 구성하였다. 즉, 여 격 및 대격 명사구 이동이 자유로운 한국어 어순 특징을 고려하여, 두 가지 어순의 출현 빈도를 동일하게 맞추어 역균형화(counterbalance)하여 어순의 효과를 통제하였다. 문장이해과제 단계에서 참여자가 예/아니오를 판단하여 키보드를 눌러 다음 문항으로 직 접 넘어가게 하였다. 실험 순서도는 Figure 2에 제시하였다.

\section{자료분석}

\section{정반응률(accuracy)}

문장이해과제에서 정반응이란 청각적으로 제시한 질문에 대해 ‘예' 혹은 ‘아니오'라고 적절하게 보인 반응이다. 적절하게 답을 고 른 경우 1 점을 부여하며, 적절하지 않을 경우 0 점으로 채점하여 점 수를 산출하였다. 이후 정반응한 문항 수를 총 문항 수로 나눈 다 음 100 을 곱하여 정반응률을 산출하였다.

\section{반응시간(response time)}

문장이해과제의 반응시간은 밀리세컨드(millisecond, ms) 단위 로 측정하였으며, 질문의 제시가 끝난 직후부터 피험자가 예/아니 오 2 개의 보기 중 한 가지 보기를 키보드에서 누른 순간까지의 시 간이다. 반응시간은 피험자가 정반응한 문항에 대해서만 분석하였 으며, 표준편차를 구했을 때 $\pm 3 \mathrm{SD}$ 범위에서 벗어나는 값은 이상 값(outlier)으로 구분하여 분석에서 제외하였다.

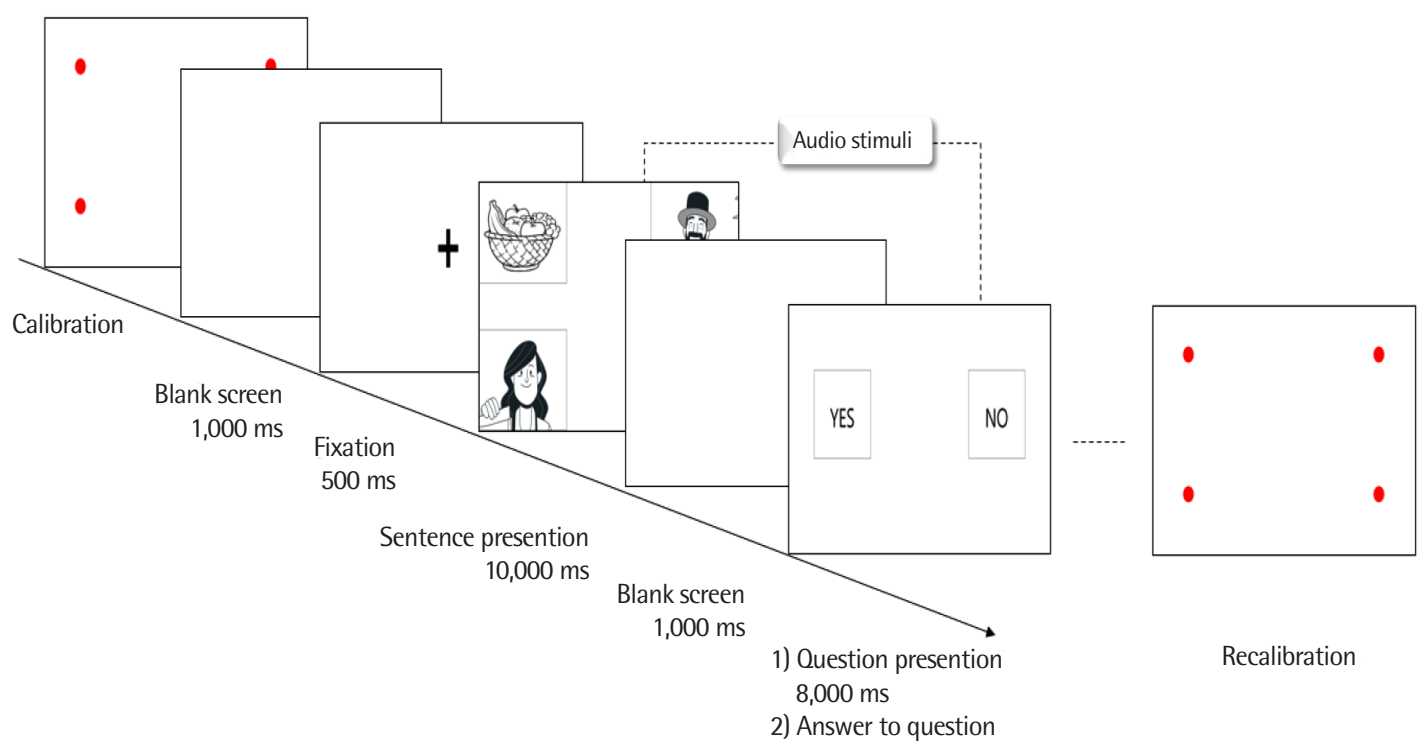

Figure 2. Experimental procedures. 
Table 4. Regions of interests from each sentence

Critical regions

\begin{tabular}{lccccc} 
& & & & & \\
\hline Type of Noun phrase in NP2 & NP1 & NP2 & ADV & NP3 & VP \\
\hline Dative & Dad-ka (Nom.) & Neighbor-ekye (Dat.) & Yesterday & Fruit-ul (Acc.) & Sell \\
Accusative & Dad-ka (Nom.) & Neighbor-ul (Acc.) & Yesterday & Hallway-esey (Loc.) & See \\
\hline
\end{tabular}

Nom. = Nominative; Dat. $=$ Dative; Acc. $=$ Accusative; Loc. $=$ Locative; NP1 = Noun phrase 1; NP2 = Noun phrase 2; ADV=Adverb; NP3= Noun phrase 3; VP=Verb phrase .

Table 5. Descriptive statistics of accuracy for each type in both groups

\begin{tabular}{llll}
\hline Group & Dative & Accusative & \multicolumn{1}{c}{ Total } \\
\hline Young $(\mathrm{N}=17)$ & $94.2(2.8)$ & $94.8(4.2)$ & $94.5(5.0)$ \\
Old $(\mathrm{N}=18)$ & $82.4(13.3)$ & $82.9(14.8)$ & $82.7(14.1)$ \\
\hline
\end{tabular}

Values are presented as mean (SD).

구간에 따른 시선고정비율(proportion of fixation)

시선고정비율은 자극이 제시되는 총 시간에서 목표 그림 자극 을 본 시간의 비율이다. 본 연구에서는 명사구(여격 vs. 대격) 제시 유형에 따른 구간별 시선고정 비율(\%)을 분석하였다. 여격 문장과 대격 문장을 4 가지 구간(NP2, $\mathrm{ADV}, \mathrm{NP} 3, \mathrm{VP})$ 으로 나눈 후, 구간 별 자극이 제시되는 총 시간 중 목표 자극에 시선을 고정한 시간을 비율로 산출하였다. 두 문장 유형의 동일한 구간인 첫 번째 명사구 는 분석에서 제외하였다. 유형별 구간 예시는 Table 4 에 제시하였다.

\section{통계적 처리}

명사구(여격 vs. 대격) 제시 유형에 따른 문장이해과제의 정반응 률, 반응시간에서 집단 간 유의한 차이가 있는지 알아보기 위하여 집단(청년층/노년층) $\times$ 명사구 제시 유형(여격 vs. 대격)의 이원혼 합분산분석(two-way mixed ANOVA)을 실시하였다. 각 명사구(여 격 vs. 대격) 제시 유형별 구간에 따른 시선고정비율에서 집단 간차 이가 유의한지 알아보기 위하여 집단(청년층/노년층) $\times$ 구간(NP2/ $\mathrm{ADV} / \mathrm{NP} 3 / \mathrm{VP}$ ) 이원혼합분산분석(two-way ANOVA)을 실시하였 다. 이를 위해 SPSS ver 2.0 (SPSS Inc., Chicago, IL, USA) 프로그램 을 사용하였다.

\section{연구결과}

\section{명사구 제시 유형에 따른 집단 간 정반응률}

문장이해과제에서 명사구(여격 vs. 대격) 제시 유형에 따른 집단 간 정반응률의 차이를 알아보고자 개체 간 요인을 집단, 개체 내 요 인을 명사구 제시 유형으로 하는 이원혼합분산분석 (two-way mixed ANOVA)를 실시하였다

청년층과 노년층 간 집단에 대한 주효과가 통계적으로 유의하였

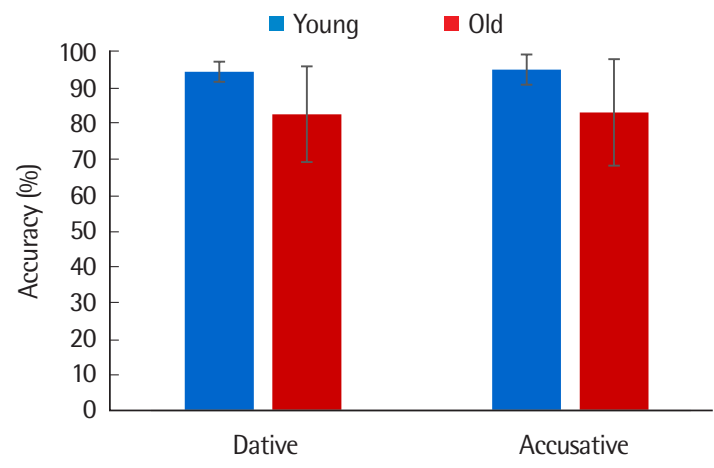

Figure 3. Accuracy of task trials for each type in both groups.

다 $\left(F_{(1,33)}=13.117, p<.01\right)$. 즉, 노년층 집단의 평균이 $82.7 \%$ 로 청년 층 집단의 평균 $94.5 \%$ 에 비해 유의하게 낮은 것으로 나타났다. 유형 에 따른주효과는 통계적으로 유의하지 않았다 $\left(F_{(1,33)}=0.183, p=.672\right)$. 또한 집단과 유형에 대한 이차상호작용이 통계적으로 유의하지 않 았다 $\left(F_{(1,33)}=0.001, p=.973\right)$. 집단 간 명사구 제시 유형에 따른 문 장이해과제 정반응률의 기술통계 결과는 Table 5, Figure 3 과 같다.

\section{명사구 제시 유형에 따른 집단 간 반응시간 분석}

문장이해과제에서 명사구 제시 유형(여격 vs. 대격)에 따른 집단간 반응시간의 차이를 알아보고자 이원혼합분산분석(two-way mixed ANOVA)을 실시하였다. 그 결과, 집단에 대한 주효과가 통계적으로 유의하였다 $\left(F_{(1,33)}=12.278, p<.01\right)$. 즉, 노년층 집단의 평균이 $1,465.35$ $(\mathrm{ms})$ 로 청년층 집단의 평균 $937.7(\mathrm{~ms})$ 보다 유의하게 길었다. 명사구 제시 유형에 대한 주효과가 통계적으로 유의하였다 $\left(F_{(1,33)}=7.830\right.$, $p<.01)$. 대격 명사구 제시 유형에서의 반응시간이 $1,257(\mathrm{~ms})$ 으로 여 격 명사구 제시 유형에서의 반응시간 $1,146(\mathrm{~ms})$ 보다 유의하게 길었 다. 집단과 유형에 대한 이차상호작용이 통계적으로 유의하지 않았 다 $\left(F_{(1,33)}=.706, p=.537\right)$. 집단 간 명사구 제시 유형에 따른 문장이해 반응시간 기술통계 결과는 Table 6, Figure 4와 같다.

\section{명사구 제시 유형에 따른 집단 간 시선고정비율 분석} 여격 명사구 제시

여격 명사구 제시 유형에서 구간에 따른 집단 간 목표 자극 시선 
Table 6. Descriptive statistics of response time (ms) for each type in both groups

\begin{tabular}{lrrr}
\hline Group & Dative & \multicolumn{1}{c}{ Accusative } & \multicolumn{1}{c}{ Total } \\
\hline Young $(\mathrm{N}=17)$ & $898.8(270.9)$ & $976.6(358.9)$ & $937.7(314.9)$ \\
Old $(\mathrm{N}=18)$ & $1,393.1(530.7)$ & $1,537.6(592.4)$ & $1,465.35(561.6)$ \\
\hline
\end{tabular}

Values are presented as mean (SD).

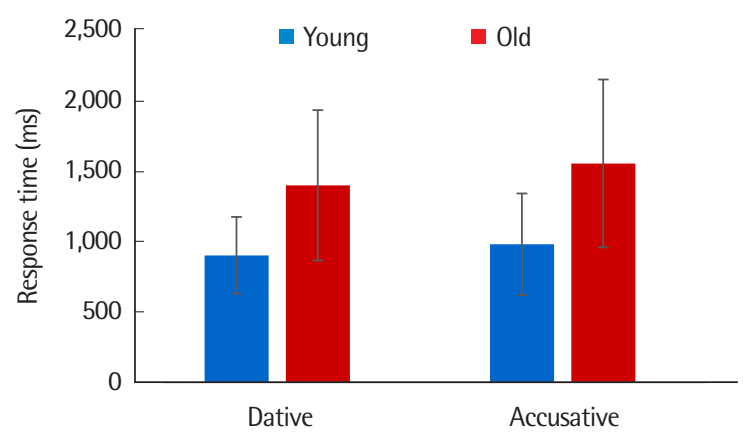

Figure 4. Response time (ms) of task trials for each type in both groups.

고정비율의 차이를 알아보고자 청년층과 노년층을 집단 간 요인, 4 개의 구간(NP2, ADV, NP3, VP)을 집단 내 요인으로 설정하는 이 원혼합분산분석(two-way mixed ANOVA)를 실시하였다. 기술통 계 결과 및 그래프는 Tables 7, 8과 Figure 5에 제시하였다. 집단에 대한 주효과가 통계적으로 유의하였다 $\left(F_{(1,33)}=4.607, p<.05\right)$. 구간 에 대한 주효과 또한 통계적으로 유의한 것으로 나타났다 $\left(F_{(1,33)}=\right.$ $24.425, p<.001)$. 사후검정을 위해 Bonfferoni를 실시하였다. NP2 와 $\mathrm{ADV}$ 의 차이 $(p<.001), \mathrm{NP} 2$ 와 NP3의 차이 $(p<.001), \mathrm{NP} 2$ 와 $\mathrm{VP}$ 에서의 차이 $(p<.001), \mathrm{ADV}$ 와 NP3의 차이 $(p<.05)$ 가 모두 유의하 였으나 $\mathrm{ADV}$ 와 $\mathrm{VP}$ 의 차이 $(p=.156), \mathrm{NP} 3$ 와 $\mathrm{VP}$ 의 차이 $(p=1.000)$ 는 유의하지 않았다. 마지막으로 집단과 구간에 대한 이차상호작용 도 통계적으로 유의하였다 $\left(F_{(1,33)}=3.992, p<.05\right)$. 사후검정을 위해 일원배치분산분석(one-way ANOVA)을 실시하였다. 이차상호작 용은 NP3 구간과 VP 구간에서 노년층의 평균 시선고정비율이 청 년층의 평균 시선고정비율보다 유의하게 낮은 것에 기인한다.

\section{대격 명사구 제시}

대격 명사구 제시 유형에서 구간에 따른 집단 간 목표 자극 시선 고정비율의 차이를 알아보기 위해 청년층과 노년층을 집단 간 요 인, 4 개의 구간(NP2, ADV, NP3, VP)을 집단 내 요인으로 하는 이 원혼합분산분석(two-way mixed ANOVA)을 실시하였다. 기술통 계 결과와 그래프는 Tables 9, 10, Figure 6과 같다. 집단에 대한 주효 과가 통계적으로 유의하지 않았다 $\left(F_{(1,33)}=3.139, p=.086\right)$. 구간에
Table 7. Descriptive statistics of proportion of target fixation for each phrase in dative type of both groups

\begin{tabular}{lrrrr}
\hline Group & NP2 & \multicolumn{1}{c}{ ADV } & \multicolumn{1}{c}{ NP3 } & \multicolumn{1}{c}{ VP } \\
\hline Young $(\mathrm{N}=17)$ & $15.2(7.6)$ & $27.8(10.0)$ & $36.8(17.9)$ & $35.5(18.0)$ \\
Old $(\mathrm{N}=18)$ & $16(5.8)$ & $23.7(7.6)$ & $25.3(7.3)$ & $25.2(9.9)$ \\
\hline
\end{tabular}

Values are presented as mean (SD).

$\mathrm{NP2}=$ Noun phrase $2 ; \mathrm{ADV}=$ Adverb; NP3 = Noun phrase 3; VP=Verb phrase.

Table 8. ANOVA results from fixation proportion on the target stimulus for each group in dative type

\begin{tabular}{lrrrc}
\hline & Sum of squares & df & Mean square & $F$ \\
\hline Between factor & & & & \\
$\quad$ Group & $1,371.455$ & 1 & $1,371.455$ & $4.607^{*}$ \\
Error & $9,823.880$ & 33 & 297.693 & \\
Within factor & & & & \\
Types & $5,334.448$ & 3 & $1,778.149$ & $24.425^{* * *}$ \\
Types $\times$ Group & 856.660 & 3 & 285.553 & $3.992^{*}$ \\
Error & $7,207.303$ & 99 & 72.801 & \\
\hline
\end{tabular}

${ }^{*} p<.05,{ }^{* * *} p<.001$.

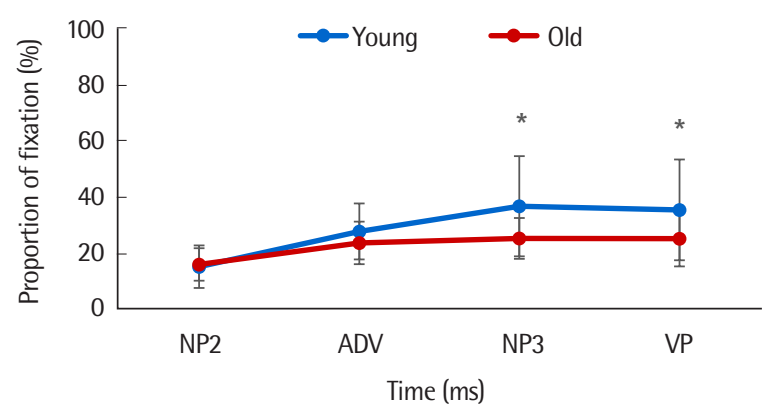

Figure 5. Proportion of target fixation for each phrase in dative type of both groups.

$\mathrm{NP2}=$ Noun phrase $2 ; \mathrm{ADV}=$ Adverb; $\mathrm{NP3}=$ Noun phrase $3 ; \mathrm{VP}=$ Verb phrase

따른 주효과가 통계적으로 유의한 것으로 나타났다 $\left(F_{(1,33)}=23.332\right.$, $p<.001)$. 사후검정을 위해 Bonfferoni를 실시하였다. NP2와 ADV 의 차이 $(p<.05), \mathrm{NP} 2$ 와 $\mathrm{NP} 3$ 의 차이 $(p<.001), \mathrm{NP} 2$ 와 $\mathrm{VP}$ 의 차이 $(p<.001), \mathrm{ADV}$ 와 $\mathrm{NP} 3$ 의 차이 $(p<.001) \mathrm{ADV}$ 와 $\mathrm{VP}$ 에서의 차이 $(p<.05)$ 가 유의하였으며 NP3와 VP에서의 차이가 유의하지 않았 다. 마지막으로 집단과 구간에 따른 이차상호작용이 유의하지 않 았다 $\left(F_{(1,33)}=3.229, p=.054\right)$.

\section{논의 및 결론}

본 연구는 노년층의 문장처리 과정, 그 중에서도 의미역 처리 과 정에 대해 살펴보고자 하였으며 구체적인 목표는 다음과 같다. (1) 
Table 9. Descriptive statistics of proportion of target fixation for each phrase in accusative type of both groups

\begin{tabular}{lcccc}
\hline Group & NP2 & ADV & NP3 & VP \\
\hline Young (N=17) & $18.1(5.3)$ & $26.9(10.3)$ & $37.13(18.08)$ & $36.55(16.5)$ \\
Old ( $=18)$ & $19(7.03)$ & $23.18(5.97)$ & $28.46(11.53)$ & $26.75(9.3)$ \\
\hline
\end{tabular}

Values are presented as mean (SD).

$\mathrm{NP} 2=$ Noun phrase $2 ; \mathrm{ADV}=$ Adverb; NP3 = Noun phrase $3 ; \mathrm{VP}=$ Verb phrase .

Table 10. ANOVA results from fixation proportion on the target stimulus for each group in accusative type

\begin{tabular}{lrrrc}
\hline & Sum of squares & df & Mean square & $F$ \\
\hline Between factor & & & & \\
$\quad$ Group & 999.187 & 1 & 999.187 & 3.139 \\
Error & $10,504.966$ & 33 & 318.332 & \\
Within factor & & & & \\
Types & $4,553.607$ & 3 & $1,517.869$ & $23.332^{* * *}$ \\
Types $\times$ Group & 630.247 & 1.730 & 364.277 & 3.229 \\
Error & $6,440.410$ & 99 & 65.055 & \\
\hline
\end{tabular}

${ }^{* * *} p<.001$.

문장이해과제에서 명사구(여격 vs. 대격) 제시 유형에 따른 집단 간 정반응률 차이에 대해 알아보고자 하였다. (2) 문장이해과제에서 명사구(여격 vs. 대격) 제시 유형에 따라 집단간 반응시간에서 차이 가 있는지 알아보고자 하였다. (3) 명사구(여격 vs. 대격) 제시 유형 에 따른 구간별 의미역 예측 및 처리 시선고정비율에서 집단 간 차 이가 있는지 알아보고자 하였다. 정리하면, 문장이 제시되는 단계 에서 의미역 예측 및 처리 시선고정비율을 분석하고, 앞서 제시된 문장을 질문으로 제시했을 때의 반응에 대해 정반응률과 반응시 간을 분석하고자 하였다. 본 연구의 결과를 정리하면 다음과 같다.

\section{정반응률과 반응시간}

문장이해과제에서 노년층 집단의 정반응률이 청년층 집단의 평 균에 비해 유의하게 낮은 것으로 나타났다. 이는 노화에 따라 문장 처리능력의 정확도가 감소한다는 선행연구결과와 일치한다(Caplan, DeDe, Waters, Michaud, \& Tripodis, 2011; Stine-Morrow et al., 2010; Waters \& Caplan 2005). 한국어 문장처리를 위해서는 격 조사 정보를 단서로 이용하여 명사구 간 의미역 관계를 파악해야 하는데 형태론적 정보를 해석하는 데서 효율성이 낮은 노년층이 청년층에 비해 정확도가 떨어진 것으로 해석할 수 있다. 이 결과는 노화가 진행되면서 형태론적 정보를 처리하는 능력에 변화를 겪는 다는 선행연구와 일치하는 결과이다(Alatorre-Cruz, Silva-Pereyra, Fernández, \& Rodríguez-Camacho, 2018; Zhu, Hou, \& Yang, 2018). 격조사와 같은 형태론적 정보를 처리하는 데는 작업기억이

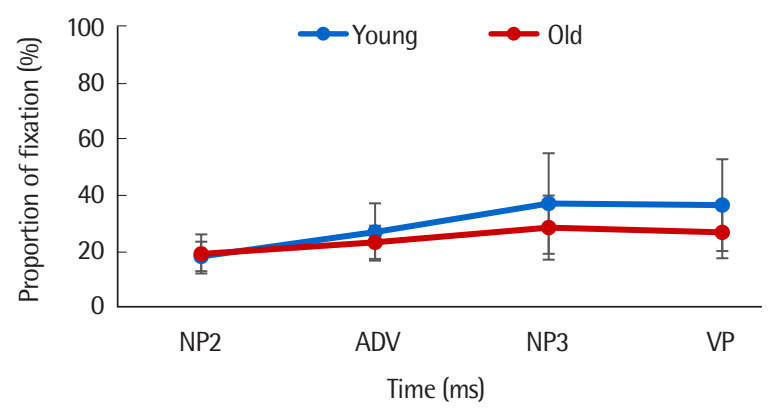

Figure 6. Proportion of target fixation for each phrase in accusative type of both groups.

$\mathrm{NP2}=$ Noun phrase $2 ; \mathrm{ADV}=$ Adverb; $\mathrm{NP3}=$ Noun phrase 3; $\mathrm{VP}=$ Verb phrase

중요한 요소로 작용하며 이는 문장처리에서 주요한 기제로 설명된 다(Carpenter, Miyake, \& Just, 1994; Just \& Carpenter, 1992; Miyake, Carpenter, \& Just, 1994). 따라서 노화에 의한 작업기억 능력 의 저하로 노년층이 낮은 정반응률을 나타낸 것으로 설명할 수 있 다. 다음으로 명사구 제시 유형에 따른 차이는 유의하지 않았는데, 이는 본 연구에서 사용된 여격 명사구 제시 유형과 대격 명사구 제 시 유형의 통사적 복잡성이 유사한 데서 기인하는 것으로 보인다. 즉 두 문장 간 처리 과정에서 인지적 부담을 유발하는 정도의 차이 가 없었던 것으로 해석할 수 있다. 문장이해과제는 앞서 제시된 문 장의 어순이나 의미역 관계를 바꾸고 질문의 형식으로 수정하여 제시되었다. 따라서 여격 문장과 대격 문장 모두 명사구가 세 개인 문장이었다(여격 문장의 경우 '아빠에게 이웃이 과일을 팔았습니 까?', 대격 문장의 경우 ‘이웃을 아빠가 복도에서 보았습니까?’). 이 는 노년층이 문장처리 과정에서 낮은 수행력을 보이지만 모든 통사 조건에서 그런 것은 아니라는 선행연구결과와 일치한다(Park, 2014). 다시 말해 노년층이 모든 통사적 조건에서 문장처리에 어려 움을 보이는 것은 아니며, 인지적 자원이 많이 요구되는 과제에서 수행력 저하가 나타남을 알 수 있다. 그러나 노년층의 수행력이 논 항의 수가 같은 두 문장 조건 모두에서 청년층과 비교해 더 낮다는 것은 노화로 인한 문장처리 능력의 저하를 보여주는 근거라고 할 수있다.

문장이해과제에서 노년층 집단의 반응시간이 청년층 집단의 반 응시간보다 길었다. 이는 노화가 진행되며 인지 기능의 저하로 인해 문장처리의 속도와 효율성이 저하된다는 선행연구와 일치하는 결 과이다(Cerella \& Hale, 1994). 격조사를 활용하는 능력 차이와 더 불어 노년층과 청년층의 서로 다른 전략 사용도 결과에 영향을 준 것으로 보인다(Braver, Paxton, Locke, \& Barch, 2009). 청년층은 사 전(proactive) 전략을 사용하는 반면 노년층은 반응적(reactive) 전 략을 사용한다. 이에 따르면 청년층의 경우 사건이 발생하기 전 예 
측에 근거하여 처리하는 반면 노년층은 사건이 일어난 후에 반응 하여 문제를 해결한다. 따라서 노년층의 느린 반응시간은 청년층처 럼 예측에 근거하여 질문을 처리하지 않고 질문을 다 들은 후에 처 리했기 때문으로 해석할 수 있다. 다음으로 명사구 제시 유형에 따 른 반응시간 차이를 분석한 결과, 대격 문장에서의 반응시간이 여 격 문장에서의 반응시간보다 길었다. 즉 대격 명사구가 선행하는 '-을 -가' 유형의 질문에서의 반응시간이 여격 명사구가 선행하는 '-에게 -가' 유형에서의 반응시간보다 길었다. 이는 어순 전형성 (word order canonicity)으로 설명할 수 있는 결과이다. 의미역이 비 전형적인 순서로 배열될 때 통사적 복잡성이 증가하며(Miyake et al., 1994), 전형(canonical) 어순과 비전형(noncanonical) 어순 중 일반 적으로 비전형 어순을 처리할 때 더 많은 인지적 처리 부담이 증가 한다(Koizumi et al., 2014). 한국어는 비교적 자유로운 어순을 따르 지만 기본 어순은 SOV 어순이다(Im, 2007). 두 유형의 질문이 모두 주어가 후행하는 비전형적 조건임을 고려할 때, 대격 명사구가 선 행하는 질문에서 반응시간이 더 긴 이유는 한국어 사용자가 대격 명사구 선행 문장 유형을 보다 비전형 어순으로 받아들이며 이에 따라 더 긴 시간을 필요로 하기 때문으로 추측할 수 있다. 그러나 앞서 서술했듯 정반응률에서 두 문장 유형 간 유의한 차이가 없음 으로 미루어 볼 때 두 문장 유형의 차이가 느린 반응시간은 유발하 지만 낮은 정확도까지 유발할 정도의 통사적 복잡성을 갖지는 않 는 것으로 보인다. 이는 이차상호작용이 유의하지 않은 이유로도 볼 수 있으며, 노년층이 문장처리 시 전반적인 효율 저하를 보이지 만 이러한 저하는 통사적 복잡성이 증가하는 경우 청년층에게도 유사하게 적용되는 것으로 해석할 수 있다.

\section{시선고정비율}

여격 명사구 제시 유형에서 집단과 구간의 차이를 살펴보았을 때 $\mathrm{NP} 3$ 구간과 VP구간에서 노년층의 시선고정비율이 청년층에 비해 낮은 것으로 나타났다. NP3구간은 목표 자극이 제시되는 구간으 로 여격 명사구의 격조사 정보를 통해 다음 의미역을 예측하여 시 선을 고정하는 양상이 드러나는 구간이다. 이러한 구간에서 목표 자극으로의 시선고정비율이 낮다는 것은 노년층이 형태론적 정보 를 통해 의미역을 예측하는 데서 낮은 효율성을 보인다는 것을 의 미하며 이는 노년층이 적절한 의미역을 할당하는 데 청년층보다 어 려움을 보인다는 선행연구결과와 일치한다(Stine-Morrow, Ryan, \& Leonard, 2000). 시선추적기법을 사용하는 연구에서 시선고정 은 정보를 획득하고 처리하는 과정을 의미한다는 점으로 미루어 볼 때(Rayner, 1998), 노년층은 제한된 인지 자원으로 정보를 통합 하고 의미역을 처리하기 때문에 방해 자극에 시선을 고정하는 비
율이 높아 다른 시각적 자극에 방해를 받아 시선이 분산되어 목표 자극으로의 시선고정비율이 낮은 것으로 해석할 수 있다. 또한 VP 구간은 문장이 마무리되는 구간으로 문장의 통합이 일어나는 구 간이다(Just \& Carpenter, 1980; Rayner, Kambe, \& Duffy, 2000). 이 구간에서 노년층의 시선고정비율이 낮은 것은 문장을 통합하는 능력이 저하되어 노년층이 청년층에 비해 문장처리가 효율적이지 못하다는 것을 의미한다.

추가적으로 NP2, $\mathrm{ADV}$ 구간과 목표 자극이 제시되는 NP3구간 에서 시선고정비율의 유의한 차이가 나타났다. 이를 통해 여격 명 사구가 제시될 때는 목표 자극으로의 시선고정비율이 낮다가 부사 가 제시되는 구간부터 동사가 제시되는 구간까지 시선고정비율이 높아진 것을 알 수 있다. 이는 청년층과 노년층 모두 여격 명사구에 서 격조사 정보를 통해 이후의 의미역을 예측하여 목표 자극으로 시선을 고정하였음을 의미한다. 따라서 한국어 문장처리 시 명사 구의 격조사 정보를 통해 의미역을 예측할 수 있다는 선행연구결과 (Lee, 2019)와 일치한다.

대격 명사구 제시 유형에서 집단과 구간의 차이를 살펴보았을 때, 여격 명사구 제시 유형과 달리 NP3구간과 VP구간에서 상호작 용이 유의하지는 않았다. 그러나 유의한 차이 $(p=.054)$ 에 근접한 차이를 통해 여격 문장과 마찬가지로 노년층 집단이 앞서 제시된 대격 명사구 정보를 활용해 의미역을 예측하고 확정하는 데 어려 움을 보이는 것이라고 추측할 수 있다.

문장이해과제에서는 대격 명사구 제시 유형에서 집단 간 차이가 유의하였는데 시선고정비율에서는 차이가 유의하지 않았다. 대격 문장의 경우 대격 명사구 이후에 동사가 뒤따르는 문장이 많지만 한국어의 어순이 자유롭기 때문에 다른 문장 성분이 뒤따라 나올 수도 있다. 다시 말해 대격 명사구 제시 후에 본 연구에서 설정한 목 표 자극인 장소가 아닌 대상이 제시되어도 의미 해석에는 큰 무리 가 없다. 따라서 대격 명사구 제시 유형에서는 이후에 예측할 수 있 는 의미역에 대한 제약이 적다. 본 이유로 대격 명사구 유형에서 목 표 의미역에 해당하는 자극인 장소가 아닌 다른 자극으로 시선이 분산된 것으로 보인다. 통사적 제약이 낮은 문장의 경우 청년층 또 한 정확한 의미역 예측 및 처리에 방해를 받을 수 있음을 의미한다.

\section{종합논의 및 제한점}

본 연구를 통해 동사가 문장의 마지막에 등장하는 한국어에서 도 언어 처리는 점진적 처리를 따른다는 것을 확인할 수 있었다. 그 러나 노화가 의미역 예측 및 처리에 영향을 미치며 효율적인 문장 처리에 영향을 미친다는 것도 확인할 수 있었다. 구체적으로, 노년 층이 격조사가 결합된 명사구 정보를 활용해 의미역 관계를 파악 
할 수는 있으나, 제한된 인지 기능으로 인해 청년층보다 정확도가 낮고 반응시간이 긴 것을 확인할 수 있었다. 또한 오프라인 측정치 와 일치되는 결과로, 시선추적 분석에서도 노년층이 목표 자극에 대한 시선고정비율이 낮은 것으로 보아 명사구의 정보를 단서로 활 용하여 적절한 의미역을 할당하는 능력이 청년층에 비해 낮다는 것을 알 수 있었다. 이러한 결과를 통해 노년층이 의사소통과정에 서 느끼는 어려움에 대한 이해를 높일 수 있을 것으로 기대한다. 본 연구의 제한점을 보완한다면 보다 의미 있는 연구가 될 것으로 보 인다. 본 연구에서는 문장 어순을 역균형화하여 통제하여 독립변 수로 따로 분석하지 않았다. 하지만, 한국어의 자유어순 특징을 고 려할 때, 어순 변화를 통한 효과를 살펴보는 것은 매우 흥미로운 요 소이므로 향후 연구에서 어순을 독립변수로 설정하여, 이에 대한 효과를 살펴본다면, 노년층의 질문 이해 양상에 대한 보다 심도있 는 연구가 가능할 것으로 생각된다. 또한 본 연구는 실험 대상자 중 여성 성별의 비율이 높으며 총 대상자 수가 제한적이라는 점을 고 려하여 해석할 필요가 있으며, 향후 이러한 점을 보완하여 연구를 확장할 수 있기를 기대한다. 실시간 언어처리 연구의 경우 많은 수 의 대상자를 포함하기가 어렵다는 단점이 있지만 오프라인 문장처 리에서는 파악할 수 없는 실시간 처리 과정을 살펴볼 수 있다는 장 점이 있다. 따라서 향후 연구에서는 보다 다양한 연령대, 성별, 교육 년수 등의 인구통계학적 요소를 반영하여 이러한 요소들이 실시간 한국어 문장처리에 미치는 영향을 고찰한다면 일반화를 확장할 수 있는 기초연구가 될 것으로 사료된다.

\section{REFERENCES}

Team, A. (2020). Audacity (R): free audio editor and recorder [computer program]. Version 2.4.2.

Alatorre-Cruz, G. C., Silva-Pereyra, J., Fernández, T., Rodríguez-Camacho, M. A. (2018). Poor working memory performance in healthy elderly adults with electroencephalographic risk of cognitive decline affects syntactic processing. Clinical Neurophysiology, 130(12), 2222-2230.

Altmann, G. T. M., \& Kamide, Y. (1999). Incremental interpretation at verbs: restricting the domain of subsequent reference. Cognition, 3(17), 247-264.

Braver, T. S., Paxton, J. L., Locke, H. S., \& Barch, D. M. (2009). Flexible neural mechanisms of cognitive control within human prefrontal cortex. Proceedings of the National Academy of Sciences, 106(18), 7351-7356.

Brown-Schmidt, S., \& Tanenhaus, M. K. (2008). Real-time investigation of referential domains in unscripted conversation: a targeted language game approach. Cognitive Science, 32(4), 643-684.
Carpenter, P. A., Miyake, A., \& Just, M. A. (1994). Working memory constraints in comprehension: evidence from individual differences, aphasia, and aging. In M. A. Gernsbacher (Ed.), Handbook of psycholinguistics, (pp. 10751122). San Diego, CA: Academic Press.

Caplan, D., DeDe, G., Waters, G., Michaud, J., \& Tripodis, Y. (2011). Effects of age, speed of processing, and working memory on comprehension of sentences with relative clauses. Psychology and Aging, 26(2), 439-450.

Cerella, J., \& Hale, S. (1994). The rise and fall in information-processing rates over the life span. Acta Psychologica, 86(2-3), 109-197.

Christensen, K. J., Multhaup, K. S., Nordstrom, S., \& Voss, K. (1991). A cognitive battery for dementia: development and measurement characteristics. Psychological Assessment: A Journal of Consulting and Clinical Psychology, 3(2), 168-174.

Cooper, R. M. (1974). The control of eye fixation by the meaning of spoken language: a new methodology for the real-time investigation of speech perception, memory, and language processing. Cognitive Psychology, 6(1), 84-107.

Federmeier, K. D., McLennan, D. B., De Ochoa, E., \& Kutas, M. (2002). The impact of semantic memory organization and sentence context information on spoken language processing by younger and older adults: An ERP study. Psychophysiology, 39(2), 133-146.

Ferreira, F., \& Cokal, D. (2015). Sentence processing. In G. Hickok \& S. L. Small (Eds.), Neurobiology of language (pp. 265-274). New York, NY: Academic Press.

Gordon-Salant, S., \& Fitzgibbons, P. J. (2004). Effects of stimulus and noise rate variability on speech perception by younger and older adults. The Journal of the Acoustical Society of America, 115(4), 1808-1817.

Hagoort, P., \& Berkum, V. J. (2007). Beyond the sentence given the resolution of case conflicts from a neurophysiological perspective. Philosophical Transactions of The Royal Society B, 362(1481), 801-811.

Hall, J. E., Horne, A. O. V., McGregor, K. K., \& Farmer, T. A., (2018). Deficits in the use of verb bias information in real-time processing by college students with developmental language disorder. Journal of Speech, Language, and Hearing Research, 62(2), 337-355.

Hwang, S. H., \& Sung, J. E. (2019). Aged-related differences in the predictability of verb-thematic roles: an eye-tracking study. Communication Sciences \& Disorders, 24(2), 447-459.

Im, H. B. (2007). Language typological approach to word order and basic word order of Korean. Sogang, 22, 53-120.

Jang, J., \& Sung, J. E. (2020). Age-related differences in sentence processing of 
who-questions: an eye-tracking study. Communication Sciences \& Disorders, 25(2), 382-398.

Just, M. A., \& Carpenter, P. A. (1980). A theory of reading: from eye fixations to comprehension. Psychological Review, 87(4), 329-335.

Just, M. A., \& Carpenter, P. A. (1992). A capacity theory of comprehension: Individual differences in working memory. Psychological Review, 99(1), 122-149.

Kamide, Y., Altman, G. T. M., \& Haywood, S. L. (2003). The time-course of prediction in incremental sentence processing: evidence from anticipatory eye movements. Journal of Memory and Language, 49(1), 133-156.

Kang, S., Kim, D., Seok, D., Cho, H., \& Choi, K. (2001). Language rehabilitation program of the aged disease. Communication Disorders, 24(2), 51-78.

Kang, Y. (2006). A Normative Study of the Korean-Mini Mental State Examination (K-MMSE) in the elderly. Korean Journal of Psychology: General, 25(2), 1-12.

Kang, Y., Jang, S. M., \& Na, D. L. (2012). Seoul Neuropsychological Screening Battery 2nd ed. (SNSB-II). Seoul: Human Brain Research \& Consulting.

Kang, Y. K., Lee, E. S., Yoon, S. W., Shim, H. J., \& An, Y. (2015). The effect of high frequency sensorineural hearing loss on auditory temporal resolution: gaps-in-noise test performance in older and young adults with normal hearing. Korean Society of Otorhinolaryngology-Head and Neck Surgery, 58(12), 841-847.

Kang, Y., \& Na, D. L. (2003). Seoul verbal learning test. Incheon: Human Brain Research \& Consulting Co.

Kemmer, L., Coulson, S., De Ochoa, E., \& Kutas, M. (2004). Syntactic processing with aging: an event-related potential study. Psychophysiology, 41(3), 372-384.

Kim, J., Sung, J. E., Lee, S. E., \& Sim, H. S. (2018). ERP components associated with locality dependency of time references between young and elderly adults. Communication Sciences \& Disorders, 23(1), 129-145.

Kim, J. (2020). The Characteristics of visual perception attentional focus in eye tracking experiments of the elderly. Journal of the Korean Institute of Interior Design, 29(4), 35-44.

Kim, J. W., \& Kim, H. H. (2009). Communicative ability in normal aging: a review. Korean Journal of Communication \& Disorders, 14(4), 495-513.

Kim, Y., \& Woo, J. (2007). The processing of thematic role information in Korean verbs. Korean Journal of Cognitive Science, 18(2), 91-112.

Koizumi, M., Yasugi, Y., Tamaoka, K., Kiyama, S., Kim, J., Sian, J. E. A., \& Mátzar, L. P. O. G. (2014). On the (non) universality of the preference for subject-object word order in sentence comprehension: a sentence-pro- cessing study in Kaqchikel Maya. Language, 90(3), 722-736.

Lee, M. (2019). Effects of case-marking on the anticipatory processing of Korean sentences. Journal of Cognitive Science, 20(3), 339-364.

Miyake, A., Carpenter, P. A., \& Just, M. A. (1994). A capacity approach to syntactic comprehension disorders: making normal adults perform like aphasic patients. Cognitive Neuropsychology, 11(6), 671-717.

National Institute of Korean Language. (2005). Frequency in use of modern Korean. Seoul: Author.

Park, M. K., Cho, E., \& Chung, W. (2016). Auditory sentence processing of morpho-syntactic and semantic anomalies: an event related potential study. Studies in Generative Grammar, 26(4), 373-394.

Park, Y. (2014). Syntactic ambiguity resolution and roles of cognitive functions in aging during on-line sentence processing. Journal of Speech-Language \& Hearing Disorders, 23(2), 9-21.

Rayner, K. (1998). Eye movements in reading and information processing: 20 years of research. Psychological Bulletin, 124(3), 372-422.

Rayner, K., Kambe, G., \& Duffy, S. A. (2000). The effect of clause wrap-up on eye movements during reading. The Quarterly Journal of Experimental Psychology, 53A(4), 1061-1080.

Rayner, K., Reichle, E. D., Stroud, M. J., Williams, C. C., \& Pollatsek, A. (2006). The effect of word frequency, word predictability, and font difficulty on the eye movements of young and older readers. Psychology and Aging, 21(3), 448-465.

Schneider, B. A., Daneman, M., \& Pichora-Fuller, M. K. (2002). Listening in aging adults: from discourse domprehension to psychoacoustics. Revue Canadienne de Psychologie Experimentale, 56(3), 139-152.

Schwanenflugel, P. J., \& LaCount, K. L. (1988). Semantic relatedness and the scope of facilitation for upcoming words in sentences. Journal of Experimental Psychology: Learning, Memory and Cognition, 14(2), 344-354.

Stine-Morrow, E. A. L., Ryan, S., \& Leonard, J. S. (2000). Age differences in on-line syntactic processing. Experimental Aging Research, 26(4), 315-322.

Stine-Morrow, E. A. L., Noh, S. R., \& Shake, M. C. (2010). Age differences in the effects of conceptual integration training on resource allocation in sentence processing. Quarterly Journal of Experimental Psychology, 63(7), 14301455.

Tanenhaus, M. K., Carlson, G., \& Trueswell, J. C. (1989). The role of thematic structures in interpretation and parsing. Language and Cognitive Process, 4(3/4), 211-234.

Waters, G. S., \& Caplan, D. (2001). Age, working memory, and on-line syntactic processing in sentence comprehension. Psychology and Aging, 16(1), 
128-144.

Wingfield, A., \& Grossman, M. (2006). Language and the aging brain: patterns of neural compensation revealed by functional brain imaging. $\mathrm{Neu}$ rophysiology, 96(6), 2830-2839.

Wlotko, E. W., \& Federmeier, K. D. (2012). Age-related changes in the im- pact of contextual strength on multiple aspects of sentence comprehension. Psychophysiology, 49(6), 770-785.

Zhu, Z., Hou, X., \& Yang, Y. (2008). Reduced syntactic processing efficiency in older adults during sentence comprehension. Frontiers in Psychology, 9, 243-252. 
Suji Kim, et al. • Effects of the Noun Types on Sentence Processing

Appendix 1. Stimuli sentences

\begin{tabular}{|c|c|}
\hline Dative & Accusative \\
\hline 아빠가 이웃에게 어제 과일을 팔았다 & 아빠가 이웃을 어제 복도에서 만났다 \\
\hline 삼촌이 청년에게 오늘 상자를 부쳤다 & 삼촌이 청년을 오늘 동네에서 보았다 \\
\hline 이모가 학생에게 해마다 선물을 전달했다 & 이모가 학생을 해마다 교회에서 맞이했다 \\
\hline 고모가 소년에게 매주 우유를 주었다 & 고모가 소년을 매주 학교에서 맡았다 \\
\hline 할머니가 소녀에게 매일 한글을 가르쳤다 & 할머니가 소녀를 매일 거리에서 지나쳤다 \\
\hline 삼촌이 노인에게 직접 자전거를 건넸다 & 삼촌이 노인을 직접 고향에서 맞았다 \\
\hline 누나가 남자에게 함부로 신문을 던졌다 & 누나가 남자를 함부로 거실에서 때렸다 \\
\hline 며느리가 아이에게 아침에 이불을 덮었다 & 며느리가 아이를 아침에 병원에서 낳았다 \\
\hline 여동생이 선배에게 이따금 작품을 소개했다 & 여동생이 선배를 이따금 모임에서 배제했다 \\
\hline 엄마가 직원에게 매달 월급을 지급했다 & 엄마가 직원을 매달 회사에서 평가했다 \\
\hline 누나가 후배에게 그만 음료를 흘렸다 & 누나가 후배를 그만 계단에서 밀었다 \\
\hline 오빠가 여자에게 여러번 시계를 선물했다 & 오빠가 여자를 여러번 도시에서 목격했다 \\
\hline 이모부가 아저씨에게 그대로 무기를 휘둘렀다 & 이모부가 아저씨를 그대로 운동장에서 일으켰다 \\
\hline 여동생이 소년에게 금방 물감을 쏟았다 & 여동생이 소년을 금방 학원에서 찾았다 \\
\hline 아빠가 노인에게 얼른 커피를 내줬다 & 아빠가 노인을 얼른 물속에서 구했다 \\
\hline 고모부가 아이에게 항상 안경을 부탁했다 & 고모부가 아이를 항상 집안에서 돌보았다 \\
\hline 언니가 청년에게 일찍 음식을 제공했다 & 언니가 청년을 일찍 창고에서 발견했다 \\
\hline 할머니가 여자에게 오후에 서류를 제출했다 & 할머니가 여자를 오후에 마을에서 기다렸다 \\
\hline 언니가 학생에게 종종 편지를 보냈다 & 언니가 학생을 종종 교실에서 도왔다 \\
\hline 며느리가 이웃에게 급히 전화를 걸었다 & 며느리가 이웃을 급히 공원에서 불렀다 \\
\hline 엄마가 남자에게 어느새 소금을 뿌렸다 & 엄마가 남자를 어느새 시장에서 놓쳤다 \\
\hline 오빠가 아저씨에게 결국 자동차를 판매했다 & 오빠가 아저씨를 결국 경찰서에서 용서했다 \\
\hline 이모부가 후배에게 계속 구두를 자랑했다 & 이모부가 후배를 계속 직장에서 비난했다 \\
\hline
\end{tabular}




\section{국문초록}

\section{여격 및 대격 명사구 제시 유형이 노년층의 문장처리에 미치는 영향: 시선추적 연구}

\section{김수지 · 성지은}

이화여자대학교 대학원 언어병리학과

배경 및 목적: 본 연구에서는 노년층과 청년층을 대상으로 명사구 제시 유형에 따른 문장처리 과정에 차이가 있는지 알아보고자 하였 다. 방법: 청년층 20 명과 노년층 20 명을 대상으로 의미역 예측시선고정비율(\%), 문장이해과제 정반응률(\%) 및 반응시간(ms)을 분석하 였다. 결과: 첫째, 문장이해과제에서 노년층의 정반응률이 유의하게 낮았다. 앞서 제시된 문장의 형태를 기억하고 회상하는데 필요한 인지적 자원의 차이로 청년층에 비해 정확도가 떨어지는 것으로 볼 수 있다. 둘째, 문장이해과제에서 노년층의 반응시간이 유의하게 길 었다. 이는 노화에 따라 문장처리의 효율성이 떨어져 더 긴 처리 시간이 필요하기 때문으로 보인다. 셋째, 여격 명사구 제시 유형에서 구 간에 따른 시선고정비율 차이가 유의하였다. 대격 명사구 제시 유형에서도 구간에 따른 차이가 유의하였다. 이는 노년층과 청년층 모두 명사구 정보를 통하여 의미역을 점진적으로 처리한다는 것을 보여주는 결과이다. 그러나 목표 자극이 제시되는 구간과 동사 구간에서 의 시선고정비율이 노년층에서 유의하게 낮은 것으로 보아 노년층이 격조사 정보를 활용하여 올바른 의미역을 할당하는데 어려움을 보인 것으로 해석할 수 있다. 논의 및 결론: 본 연구를 통해 노화가 실시간 문장처리에 영향을 미친다는 것을 확인할 수 있었다. 노년층 과 청년층 모두 명사구 정보를 통해 문장을 점진적으로 처리하지만 이 과정에서 노년층의 의미역 할당 정확도가 청년층에 비해 낮으며 처리 시간도 길다는 것을 알 수 있었다. 특히나 대격 명사구 제시 유형에서 반응시간이 긴 것을 통해 비전형적 어순의 문장을 처리할 때 어려움이 증가한다는 것을 확인하였다.

핵심어: 노화, 문장처리, 시선추적, 명사구

본 연구는 2021년도 정부(과학기술정보통신부)의 재원으로 국가과학기술연구회 창의형 융합연구사업(No. CAP21051-000)의 지원을 받아 수행된 연구임.

본 논문은 제1저자(김수지)의 석사학위논문을 발췌 및 수정한 것임.

\section{참고문헌}

강수균, 김동연, 석동일, 조홍중, 최경희 (2001). 노인성 질환에 대한 언어 재활 프로그램. 난청과언어장애, 24(2), 51-78. 강연욱 (2006). K-MMSE (Korean-mini mental state examination)의 노인 규준 연구. 한국심리학회지: 일반, 25(2), 1-12. 강연욱, 나덕렬 (2003). 서울언어학습검사(SVLT). 인천: 휴브알엔씨. 강연욱, 장승민, 나덕렬 (2012). 서울신경심리검사 2판(SNSB-II). 서울: 휴브알엔씨. 강용경, 이은섭, 윤상원, 심현준, 안용휘 (2015). 정상 청력인 노인과 젊은 성인에서 고음역 감각신경성 난청이 청각의 시간적 해상도에 미치는 영향:

Gaps-In-Noise 검사수행력. 대한이비인후과학회지 두경부외과학, 58(12), 841-847.

국립국어원 (2005). 한국어 사용빈도 조사. 서울: 국립국어원. 김영진, 우정희 (2007). 한국어 동사의 의미역정보 처리과정. 인지과학, 18(2), 91-112. 김정완, 김향희 (2009). 노년층 의사소통능력에 대한 문헌연구. 언어청각장애연구, 14(4), 495-513. 김종하 (2020). 고령자의 시선추적 실험에 나타난 시지각 주의집중 특성. 한국실내디자인학회 논문집, 29(4), 35-44. 김지인, 성지은, 이수은, 심현섭 (2018). 문장 성분 간 거리에 따른 시제 표지 처리 과정에 대한 청년층 및 노년층의 ERP 성분 비교. Communication Sciences \& Disorders, 23(1), 129-145.

박명관, 조의연, 정원일 (2016). 형태-통사 및 의미 위반의 청각적 문장처리: 사건관련전위 기반 연구. 생성문법연구, 26(4), 373-394. 
박영미 (2014). 정상노인들의 통사적으로 애매한 문장의 실시간 처리능력과 인지기능의 역할. 언어치료연구, 23(2), 9-21.

임홍빈 (2007). 어순에 관한 언어 유형적 접근과 한국어의 기본어순. 서강인문논총, 22, 53-120.

장지혜, 성지은 (2020). 시선추적을 활용한 청년층 및 노년층의 누구(who) 의문사처리 연구. Communication Sciences \& Disorders, 25(2), 382-398.

황상흠, 성지은 (2019). 시선추적을 활용한 동사의 의미역 예측 정도가 노년층 의미역 처리에 미치는 영향. Communication Sciences \& Disorders,

24(2), 447-459.

\section{ORCID}

김수지(제1저자, 대학원생 https://orcid.org/0000-0002-8155-8166); 성지은(교신저자, 교수 https://orcid.org/0000-0002-1734-0058) 